‘Arry's Bar: Condensing and Displacing on the Aylesbury Estate Jane Rendell 
From my desk in my flat on the eighteenth floor of a tower block in south London, I can see a history of London's housing design lying at my feet: from the Georgian townhouses of the estate agent's newly coined 'Walworth village' to the ragged holes in the ground where the Heygate Estate used to be; from the pointed end of the Shard at London Bridge, where soaring skyward - penthouses, I am told, contain private swimming pools and cinemas, to the 'affordable' new flats being built along the northern edge of Burgess Park, in place of the social housing provided by the slab blocks of the Aylesbury estate, some of which have already been demolished, while others lie under threat.

In was from this desk, that I wrote my last book, on transitional spaces in psychoanalysis and architecture, specifically social housing. As I drew the book to a close, I discovered that my own home was in Southwark's 'estate renewal zone'. ${ }^{1}$ Property consultants Savills had been advising the council of the need to 'unearth the potential' of public land, including 'brownfield sites', a term which for them includes fully occupied housing estates. ${ }^{2}$ According to Savills and others, post-war 'estates are not dense enough, and street style layouts should be re-introduced. ${ }^{3}$ Although new research shows refurbishment has less social and environmental cost than demolition, ${ }^{4}$ the advantage of new build is that existing residents can be moved out, and in return, following viability studies, the developers can make their non-negotiable 20 per cent profit while providing a small percentage of 'affordable housing'. ${ }^{5}$ Tenants have been displaced from central London into other boroughs, ${ }^{6}$ and leaseholders ejected from the city entirely, due to the low rates of compensation paid when the councils issue compulsory purchase orders. ${ }^{7}$ I became so angered by the council's actions, that I decided to use my academic and professional working skills to get directly involved in the fight for the Aylesbury Estate in Southwark, and to turn my fear of uncertainties around my London home into action.

One site of this action was 'Arry's Bar at Millwall Football ground in south east London. This was the venue for The Public Inquiry into the Aylesbury Compulsory Purchase Order (CPO), held in from 28 April to 1 May 2015, adjourned until 12 May, and then adjourned again until 13-4 October 2015 for the leaseholders group to gain legal representation. The multi-voiced text that follows consists of material taken from my Academic Expert Witness Statement (in plain text), ${ }^{8}$ from the Witness Statement of an Aylesbury leaseholder (in bold), ${ }^{9}$ and from the London Borough of Southwark's Statement of Case (in bold italics)..$^{10}$ Both the witness statements were submitted to Government Inspector Leslie Coffey on 23 April 2015, as part of the Inquiry and subject to cross examination by Southwark's Barrister Melissa Murphy. 
[insert image 1]

I, Jane Rendell, of The Bartlett School of Architecture, University College London (UCL), 140 Hampstead Road, London, NW1 2BX, say as follows:

\section{Professional Role}

I have been a Professor of Architecture and Art at the Bartlett School of Architecture at University College London (UCL) since 2008. I worked as an architectural designer on social housing in the 1980s and 1990s; I have an MA and PhD in architectural history. My forthcoming book looks at the destruction of 1950s/1960s welfare state housing designed and built by the London County Council (LCC), and how the democratic aspirations of the post war period to provide housing based on need have been replaced by a market-based housing model.

\section{Methodology}

\section{(1) Literature Review}

My statement is based on the following sources: (i) academic literature held in the public domain on housing, regeneration and the current London Housing Crisis, including evidencebased analyses of the Aylesbury Estate made by Professor Loretta Lees and Dr Richard Baxter; ${ }^{11}$ (ii) summaries of the on-going Aylesbury demolition on three key websites - 35\%, Southwark Notes, and Better Elephant; ${ }^{12}$ (iii) material on the redevelopment of the Aylesbury Estate since 2005 from the Southwark Council website or accessed through FOI requests.

\section{(2) Situated Knowledge}

My published research draws on my personal experience, on what Professor Donna Haraway has described as 'situated knowledge'. ${ }^{13}$ Since $2010 \mathrm{I}$ have been a resident leaseholder of a flat on the eighteenth floor of Crossmount House, on the Wyndham Estate, half a mile west of the Aylesbury Estate and the 'Order Land' ${ }^{14}$ I have been a Strategic Member of the Aylesbury Leaseholders Action Group since November 2014, through which I have first-hand knowledge and understanding of the experiences of various Aylesbury leaseholders. My 
experience as a Southwark leaseholder (over my own windows and balcony described in my statement) has highlighted for me: (i) The imbalance of power in relations between Southwark leaseholders and Southwark Council, and how Southwark Council has the power to make decisions that are extremely difficult for leaseholders to challenge without expensive legal advice. (ii) The lack of importance with which Southwark Council holds modern architecture, particularly the ways in which the views and the communal areas, which are integral to the design of 'point' and 'slab' blocks in post-war welfare state housing, are devalued with the insertion on my estate of poorly designed plastic windows and the locking off of laundry rooms. My statement is based on research given pro-bono, partly to help my neighbours, and partly as my own home is in a post-war 'point' and 'slab' block estate in Southwark's renewal zone. I will return to the relevance of this definition.

Historical Context: The Aylesbury as part of post-war Welfare State Public Housing Crossmount House, where I live, was built in 1967, it is a point-block, one of five, designed by Colin Locus, one of the architects of the renowned LCC Alton Estate at Roehampton. ${ }^{15}$ With a target population of 10,000 the Alton Estate was the largest of the L. C. C. developments, and one of the largest housing projects in Europe. Alton East pioneered 'point' blocks, based on Swedish designs, of which Crossmount House is a fine example. Alton West pioneered 'slab' blocks, based on Le Corbusier's famous Unité d'Habitation, built between 1947 and 1953 in Marseilles, ${ }^{16}$ and situated in 8.65 acres of parkland, offering views to all its inhabitants: 'everyone looks out on trees and sky'. The Unité de Marseilles, was in turn inspired by the Narkomfin Communal House in Moscow, designed by Moisei Ginzburg with Ignatii Milinis in 1928-1929, a scheme which included green space, communal facilities and whose dwelling blocks were orientated to include air, sun and access to greenery, via ribbon windows and roof gardens. ${ }^{17}$ Key to the Unité and the Narkomfin designs were the communal spaces - the spaces of 'social condensation' - specifically the wide corridors, for people to meet and socialize, later termed 'streets in the sky' by the British post war architects, Peter and Alison Smithson, and which inspired the recently refurbished Park Hill in Sheffield, ${ }^{18}$ as well as the Aylesbury. ${ }^{19}$

Current Context: The Aylesbury and 'Estate Renewal'

Much of Southwark's housing strategy for council estate 'renewal' is informed by research conducted by property consultants, Savills, who recommend that councils 'unearth the potential' of public land. ${ }^{20}$ The post-war 'point' and 'slab' blocks that make up most estates, 
including the Aylesbury, are not dense enough Savills argue; they must be replaced by mansion blocks situated on re-introduced old street layouts. ${ }^{21}$ Savills cite a report published by Create Streets, which claims that people do not like in living in post-war high-rise blocks. ${ }^{22}$ However, such viewpoints are directly countered by qualitative research, such as that conducted recently on the Aylesbury Estate by Richard Baxter whose oral history with residents on the estate counters the dominant trend to dismiss high-rise living as a failure, showing instead the importance of the high-rise view to people's sense of identity, and the pleasurable role of vertical experiences in belonging to place and in home-making. ${ }^{23}$ Loretta Lees and Ben Campkin have pointed out how unfavourable representations of post-war estates like the Aylesbury in the media, have helped to create a biased impression of a violent underworld by those who do not live there, and thus participated in building an image of a failing housing estate which requires demolition. ${ }^{24}$ As London property prices have been leveraged up to unsustainable levels, the motive for 'unearthing the potential' of public land, which depends on the demolition of post-war public housing estates, is to open them up for private investment, rather than 'the greater public benefit'. This is the context for the use of CPOs to acquire leaseholder properties.

[insert image 2]

\section{Overall Argument}

I question Southwark Council's use of Compulsory Purchase Orders to acquire leaseholder properties on the 'Order Land'. In my view, there is not a 'compelling case in the public interest', ${ }^{25}$ to 'justify interfering with the human rights of those with an interest in the land affected', ${ }^{26}$ by the use of CPOs which would go against Article 1 of the Protocol of the Convention for the Protection of Human Rights and Fundamental Freedoms. ${ }^{27}$

Article 1, Protocol 1: Protection of Property-Article 1 protects the right of individuals to the peaceful enjoyment of possessions. No individual can be deprived of his/her possessions except in the public interest and subject to the relevant national and international law. The Council recognises the potential for interference with individuals' right to peaceful enjoyment of existing and future homes upon the confirmation and implementation of the Order. $^{28}$

Notably, not all human rights operate in the same way. Few rights are absolute and thus cannot be interfered with under any circumstances. Other 'qualified' rights, including the 
aforementioned Article 6, Article 8 and Protocol 1 rights, can lawfully be interfered with or limited in certain circumstances. The extent of legitimate interference is subject to the principle of proportionality whereby a balance must be struck between the legitimate aims to be achieved by a local planning authority in seeking to bring about regeneration in the public interest against potential interference with individual human rights. It is acceptable for the Council in making the Order and the Secretary of State in confirming it to strike a balance between the legitimate aim of regeneration for the benefit of the community as a whole against potential interference with some individual rights. ${ }^{29}$

The Government Circular 06/2004, Compulsory Purchase and the Crichel Down Rules, notes that CPOs can only be taken when 'there is clear evidence that the public benefit will outweigh the private loss'.$^{30}$ The Statement of Case made by the London Borough of Southwark under Rule 7 of the Compulsory Purchase (Inquiries Procedure) Rules 2007 states that:

... a local authority must not exercise its compulsory purchase power ... unless it thinks that the development, re-development or improvement is likely to contribute to the achievement of any one of more of the following objects: (a) The promotion or improvement of the economic well-being of their area; (b) The promotion or improvement of the social well-being of their area; (c) The promotion or improvement of the environmental well-being of their area. ${ }^{31}$

The following seven aspects of Southwark's regeneration scheme are not 'in the public interest', and thus do not justify the CPO of leaseholder properties on the 'Order Land':

I made the decision to buy my home in 2003. It was because I loved the area and being close to the largest park in South East London (Burgess Park) was another attraction. Beautiful outside space with various elements which is a wonderful place for family life as well as serenity. My future benefits and my expectations would be met by having a home for life.

[insert image 3]

(1) Choosing to demolish rather than refurbish

The Conisbee report of March 2005 is a structural survey of the Aylesbury Estate 
commissioned by Southwark Council. ${ }^{32}$ Based on an assessment of the buildings, the Jesperson construction technique used to construct the Aylesbury, and the Building Regulations current at the time of construction, it concludes that the only action required is minor repairs to the 5-storey blocks. [see Statement of Case paras 5.10-15]

The LBS [The London Borough of Southwark] state that the estate is ugly, rundown and beyond economical repair and I have read this negativity from outsiders. I would like to know these people writing these things and if they have actually been on the estate and walked around - prior to the decanting and see the beauty of the estate 'every rock is someone's diamond'. That's how I would describe it. Yes there may be some miniscule flaws but nothing that cannot be ironed out with refurbishment.

In 1999 local residents started lobbying the Council to regenerate the Estate. The Council considered various options including refurbishment to respond to the concerns expressed by residents. Refurbishment options were dismissed on value for money and feasibility grounds, as a result of the complexity and magnitude of the structural, electrical and mechanical works required. ${ }^{33}$

Estates in other London Boroughs, built using the same construction system, such as Six Acres in Islington, have been refurbished rather than demolished. However, at a meeting on the 27 September 2005 Southwark decided to demolish rather than refurbish the Aylesbury. I have been unable to access information of any cost benefit analysis undertaken to determine the financial basis for the decision and a key numerical table on p. 10 of the Conisbee report is missing from the bundles of information sent to Leaseholders by Southwark.

I also believe it is a wonderful structure and it brings together all the elements of community spirit. I have made so many friends with people on the Aylesbury e.g. direct neighbours and people that I have conversed with within the lift (when they are working).

[insert image 4]

(2) Reducing the number of affordable units 
There are 566 existing units in the 'Order' land, of which 511 are social rented and 55 leasehold; these will be replaced by 830 new units of which only 406 are affordable. ${ }^{34}$ The addition of 424 units for private sale at the full market rate, against the loss of 511 social rented units, is evidence not that public benefit outweighs private loss, but of the reverse: that private benefit outweighs public loss.

The purpose of the acquisition of the Order Land is to enable demolition of the existing buildings in order to replace the 566 existing units of social and privately owned housing with a mixed tenure development comprising 815 homes. Of these, 255 will be at target rents, 92 will be intermediate (affordable homes available as shared ownership or shared equity) and 412 will be private (of which 47 will be for open market rent and the remainder for sale), as well as a further $\mathbf{5 0}$ mixed affordable tenure extra care units and 6 units for people with learning difficulties ('the Scheme'). ${ }^{35}$

My home is been taken away from me for a fraction of the cost I believe it is actually worth. This is a bitter pill to swallow.

Because of all this unnecessary stress of decanting and the hostility that comes with it. I have already suffered several heath episodes, which fatally could result in stroke or heart attacks - this due to stress.

[insert image 5]

(3) Displacing mixed communities

The 'right to buy' has produced a mixed community of estate residents - council tenants and leaseholders. This quality of mixed tenure is one of the prime features of diversity in most public housing estates across London, certainly in the Wyndham where I live, as well as the Aylesbury Estate and the 'Order Land'. Southwark Council in its Equalities Impact Assessment for Aylesbury Area Action Plan (January 2009) describes a ratio of $18 \%$ leaseholders to $82 \%$ tenants.

I have lived on the estate for over 27 years. Prior to living on the estate I spent many summers here on Aylesbury with my cousins from Latimer (my first introduction to the Aylesbury) and those were the fun years of my teenage life running around the estate and 
networking in the bag wash (laundromat). My cousins continue to live in the area and I enjoy socializing with them.

They also describe the existing residents as highly diverse in terms of ethnic composition, with $67 \%$ belonging to a minority ethnic group, and around $21 \%$ over 60 years of age. ${ }^{36}$ By its own admission, the Aylesbury Estate and the 'Order Land' within it, is already a diverse community with mixed tenure, which contradicts a key reason that Southwark Council has given for redeveloping the Aylesbury Estate to create a 'vibrant new neighbourhood'. ${ }^{37}$

An Equalities Impact Assessment was carried out as part of the AAAP. While this did not assess all of the groups with protected characteristics identified under the 2010 Equalities Act, the outcomes of that assessment are still valid and demonstrate that the overwhelming impact on local people will be positive from the redevelopment. ${ }^{38}$

You get to know so much about individuals just by a conversation in the lift on the estate and there is a large presence of community spirit. Some people you don't even know their names but you still say hi and have a long chat.

Of the 575 Aylesbury households removed from the estate to date (387 tenants and 188 leaseholders), ${ }^{39}$ just a third (195) have managed to remain in Walworth. ${ }^{40}$ Research has mapped how in the Heygate Estate, a mile to the north, tenants-were displaced from central London into other boroughs, and leaseholders ejected from the city entirely. ${ }^{41}$ If the statistics for the Aylesbury households continue to follow this pattern of dispersal then the regeneration will have the paradoxical effect of displacing precisely those people who it was apparently intended to benefit. ${ }^{42}$

The properties I have seen go no way to meet the spacious elements of my flat. The Council tax on these properties is more than the property I am living in. Moreover, I would have to pay more money in transport to move to these properties or if I moved out of the area have to find the money to get into the area to attend the hospital and other services.

A recent Government report states that 'leaseholders should be offered a like-for-like replacement of their property, or a similar offer, wherever possible', ${ }^{43}$ yet Southwark's 
options for leaseholders which include them acquiring shared ownership or equity of the new intermediate units is not realistic given the difference between the sums leaseholders are being offered for their own properties and the price of intermediate units. For example, a two bedroom flat in the Aylesbury overlooking Burgess Park on the fifth floor or above might be valued (by Southwark's valuers) between $£ 120,000$ to around $£ 200,000$ (after going to tribunal and in comparison with other test cases). However, in new development Camberwell Fields, a two bed flat overlooking Burgess Park on the fifth floor is between $£ 550,000$ and $£ 650,000,{ }^{44}$ and those on lower floors with no park view are around $£ 450,000$. So if a leaseholder wished to remain high up, and to retain their park view, in the best case example, having suffered the inconvenience, loss of earnings and stress of taking the case to tribunal, and if after financial means testing they were offered equity or shared ownership, they would need to take on between $£ 350,000$ and $£ 450,000$ of debt to cover the difference in price. And this would be subject to the availability of a suitable flat and the ability to find a mortgage provider.

There are three main options for home owners to consider, depending on their circumstances. These are: 1) Purchasing a replacement property on the open market, 2) Purchasing a replacement property through a low cost home ownership scheme with a registered provider, 3) Seeking re-housing assistance from the Council and eventually becoming a full/shared owner or tenant of a Council property. ${ }^{45}$

I am not in a position to get a mortgage because of my age and currently being unemployed so my future looks very bleak! And the uncertainty of moving away from my life-long friends, family is killing me on a daily basis. My heath continues to deteriorate waiting for my home to be.

The negotiation's with LBS has been extremely difficult and the conduct of certain parties can be called into question as they do not treat people fairly and equitably. The money on offer cannot buy another property of the same size in my area.

I am unemployed, have restricted funds and the CPO is harming my prospects for the future. This threat of a compulsory purchase order has prevented me from pursuing my goals of further study, impinged on my right to a family life, and had a negative effect on my health. 
On 18 March 2014 the Council agreed a further policy paper under which a new model of home ownership - shared equity - is now being offered (Cabinet report and minutes at CD 15). This model was introduced in response to the lack of interest of some homeowners in the shared ownership model whereby rent is payable on the retained share of the shared ownership property. With shared equity, no rent is payable on the retained portion. This option will assist with the re-housing process. The new shared equity model is available, subject to financial qualification, to all leaseholders on the Estate when they become eligible for re-housing assistance. This option will help with re-housing not just in relation to the Order Land but future phases on the Estate. ${ }^{46}$

[insert image 6]

(4) Organising the new housing according to economic status

Southwark Council in its Equalities Impact Assessment for Aylesbury Area Action Plan (January 2009), states it will not "create an area of the "haves" and "have nots". ${ }^{47}$ Yet housing at Camberwell Fields is segregated into zones - private sale, social rent, and intermediate - according to the purchasing power of the occupants/buyers. ${ }^{48}$ In phase 1a of the Aylesbury redevelopment, the units are distributed so the south-facing views over Burgess Park previously enjoyed by a mix of tenants and leaseholders will mainly benefit units for private sale on the open market. The majority of units overlooking the park and directly behind this are for sale, while the intermediate are mainly located towards the back of the site, and the far back of the site is mainly social rented units. ${ }^{49}$

The views from my living room, bedroom and kitchen and front landing are breath-taking. I can see an array of London tourist attractions e.g., the London Eye, Big Ben, Shard, Gerkin, Razor, St Paul's Cathedral, Canary Wharf, Strata Tower at the Elephant and Castle. I will no longer be able to see the sights from my windows if this CPO is granted. My family and friends come from all over the world to see these tourist attractions and go back and tell their friends about what spectacular views their cousin/friend has from her flat windows. And their friends then want to come and see for themselves so if this was such ugly deprived estate why do people so love coming to visit and moreover love living on it! 
[insert image 7]

(5) Ignoring the democratic decision-making processes

Unlike Heygate residents, who were denied a ballot on the future of their estate, Aylesbury residents were fully balloted. In $200176 \%$ of Aylesbury residents turned out to vote against a proposed stock transfer and regeneration (73\%). ${ }^{50}$ This democratic process has been ignored by Southwark who have gone ahead with privatization regardless of the majority of residents' wishes.

In 2001 the LBS proposed that the Aylesbury estate was to be refurbished. This proposal was strongly supported by residents. Refurbishment would be in the public interest and for the wellbeing of the current community of residents of the Aylesbury.

At a ballot in 2001 in relation to stock transfer, 73\% voted against and promise of refurbishment was then given by the council.

As a result I signed on the dotted line to complete my transaction of the purchase of $\mathrm{my}$ property. Then I became aware that my property was now going to be demolished. My property became immediately blighted.

You could imagine my shock and anxiety. I felt that I had been deceived. I know that I was given a discount for the property and I was informed that if I sold my property back to the LBS I would have to pay back the discount. This I could not afford. So I was now between a rock and a hard place. I am faced with the immediate threat of losing my home due to the Compulsory Purchase Order.

Consultation has continued on the specific design proposals for the Order Land. Resident feedback has been obtained on the proposals for the Scheme throughout the EU procurement process with regular stakeholder meetings being held with residents. Their feedback informed the development of the Council's requirements at every stage of the procurement process. A focus group consisting of five local residents and the director of the Creation Trust was involved at all stages and their role included meeting with bidders to help them better understand community issues and perspectives. This consultation also 
went beyond design issues and included discussions about the employment opportunities on offer, and other aspects of the regeneration process. ${ }^{51}$

[insert image 8]

(6) Prioritizing private profit over leaseholder wellbeing

Southwark Council plan to compulsorily purchase properties that they previously sold to leaseholders. However, one key financial objective of the redevelopment of the Aylesbury Estate as stated in the report of the meeting of Southwark Council on 27 September 2005 is to allow developers to make $15 \%$ profit. How can making a profit for private developers be for the public benefit? When a local authority uses statutory powers to dispossess leaseholders of their homes and life savings, to the great benefit of private capital, trust in public institutions as systems of governance is weakened.

I have seen the devastating effects that this regeneration has had on people. It has broken whole families apart, caused many to loose their jobs, resulted in children being out of school for months until Schools in other areas could take them in. Many residents are concerned about losing that support network and the health of those non-visible vulnerable residents has deteriorated.

[insert image 9]

(7) Redaction of key information concerning 'viability'

The claim made by the Aylesbury Area Action Plan that 'replacement of all the existing social rented housing would not be possible economically, ${ }^{52}$ is impossible to disprove since the viability studies and financial models that form the basis of the decisions have been redacted from key documents, and are unavailable for public scrutiny.

The LBS has reneged on the promise to allow residents to return to the footprint of the estate. The LBS initially stated that people would be allowed to return, however subsequently I was informed that there is no right to return after redevelopment has been completed.

The option to return for leaseholders is not an offer that the Council has made on any of its 
big regeneration schemes in the past and the Council has been consistent with that policy in respect of the Aylesbury estate. Option to return offers have been made on other regeneration schemes (Wooddene, Elmington) but only in respect of tenants, not leaseholders. ${ }^{53}$

When requesting information concerning the partnership deal between Southwark Council and Notting Hill Housing Trust, Southwark Council asserted that 'the public interest in providing this information does not outweigh the likely prejudice to commercial and economic interests of both the council and the third party. ${ }^{54}$ Southwark Council argues that the demolition of the 'Order Land' is in the public interest and that public benefit outweighs private loss, yet this contradicts its decision to protect the privacy of the developers' financial information, while demanding that leaseholders should have their finances means tested and open to public scrutiny.'

The intrusive means testing of leaseholders' finances is another issue, which seems unfair. Forcing leaseholders who already own their home outright to be mean tested is inequitable.

The concept of the social condenser was developed through the theoretical and later practical work of the Russian constructivists in the 1920s. An artistic and architectural philosophy that argued for art's social purpose, constructivism developed initially out of conversations at INKhUK (Institute of Artistic Culture) in Moscow in 1920-2, which was led by the establishment in 1921 of a group of artist-constructivists. ${ }^{55}$ This became the guiding principle of the OSA (Association of Contemporary Architects), which emerged in 1925 from VKhUTEMAS (Higher Artistic-Technical Studios), the state-sponsored school of design established in 1920 to train artists for industry. ${ }^{56}$ OSA's President and Vice President, Aleksandr Vesnin and Moisei Ginzburg, leading 'theorists and proponents' of constructivism, were also the editors of its journal Contemporary Architecture (Sovrenennaja architektura, SA), which lasted from 1927 to $1930 .{ }^{57}$ In the lead article of the first issue, Ginzburg called 'for a new architecture that would plan the total urban environment in such manner as to generate a "new life". ${ }^{58}$ And in a later issue from the same year, OSA argued that a new socialist society needed new architectural forms, to be designed by professional planners and 
designers through a process of experience and experiment - 'building, inhabiting, testing, and revising'.59

In constructive periods of history, i.e., in periods of the intensive formation of a new culture, what is first of all required from the architect is the invention and crystallization of social condensers for their epoch, the creation of new architectural organisms, for this epoch of designing and maintaining architectural objects - the spatial repositories for these forms of the new life. ${ }^{60}$

In this piece, I am suggesting, that on 28 April to 1 May 2015, the 12 May, and the 13 and 14 October 2015, 'Arry's Bar in Millwall Football ground became a social condenser. The room is non-descript, with melamine tables and plastic chairs, magnolia painted walls and grey contract carpet. The bar, located in the corner of the room, was a counter top service, locked behind a steel grille on the days of the Public Inquiry. There was nothing here of architectural merit, and certainly nothing designed as a 'spatial repository' for a 'form of new life'. And yet a new form of life did emerge through those sessions, fragile and transitory, who knows whether it can be maintained. 'Arry's Bar became a spatial repository for a critical opposition to the 'slow violence' enacted through Southwark's state bureaucracy. An unlikely group of people came together to resist Southwark's institutional brutality: a conservative councillor, a radical Slovenian artist and activist, the last leaseholder from the Heygate, a number of academic experts in housing, regeneration, and sustainability, and the Aylesbury leaseholders and tenants themselves, fighting for their home-for the principle of 'like for like' and for the 'right to return'.

But there is another more perverse narrative at work here, which concerns the Aylesbury's own existence as a social condenser, constructed formally at least, as one of the last in a line that can be traced back to the Unité d'Habitation, formally at least, and before that, in terms of the social agenda, to the Narkomin, whose public spaces, as described by its own residents, act as settings for communal life. ${ }^{61}$ The contorted and obfuscating logic of the CPO as the tool de jour of neo-liberal state-led regeneration must invoke public interest against private loss for its act to be justified, and yet its very 'rhetoric', as Michal Murawski pointed out to me on reading this essay, 'rests on the attempt to deny the public character of the Aylesbury Estate'. 'However', as Michal continues, so pertinently, 'if you accept the argument that the Aylesbury Estate is an inherently public social condenser, then the CPO becomes illogical: the social condenser forces us to look at residential properties as public spaces!' ... 
and not, as private properties. So perhaps what happened in 'Arry's Bar is a condensing of the Aylesbury itself? But where does that condensing leave its residents, tenants and leaseholders, those who bought property in a publicly-owned housing estate, either under 'right-to-buy' or from a previous owner?

On 15September 2016, almost two years after I completed my book on transitional spaces, I took a last look at the Aylesbury from my flat on the eighteenth floor. Experiencing the uncertainties a pending CPO can create as well as the poor treatment of leaseholders by the council, whether as a result of regeneration or the ongoing challenge of paying tens of thousands of pounds for poorly designed yet highly costly major works, had made it impossible for me to feel 'at home' in Southwark. With plans for estate renewal now shifting east to the Old Kent Road, and my own estate seemingly out of the firing line, I decided it was time to sell my flat. I displace myself.

A day later, almost a year after the Public Inquiry, it was announced that the Secretary of State for the Department of Communities and Local Government, Sajid Javid, had refused Southwark's application to compulsory purchase order the homes of Aylesbury leaseholders, on the grounds that the CPO would have a disproportionate impact on residents from black and ethnic minority backgrounds. ${ }^{62}$ As the $35 \%$ Campaign reported:

In his damning decision, the Secretary of State has said that Southwark has not fulfilled its Public Sector Equality Duty. He points out the majority of the estate (67\%) are from black or ethnic minority backgrounds and it is 'highly likely that there is a potential disproportionate impact on [these groups] who are ... likely to have to move out of the area if the Order is confirmed' ${ }^{63}$

All drawings by Judit Ferencz (2015).

\footnotetext{
${ }^{1}$ See for example http://35percent.org/2014-07-23-mystery-objector-1301/ (accessed 9 January 2017).

${ }^{2}$ See http://www.savills.co.uk/ news/article/72418/175241-0/4/2014/savills-research--london-regenerationresearch-proposal (accessed 9 January 2017). For specific reports see for example http://pdf.euro.savills.co.uk/residential---other/spotlight-public-land.pdf (accessed 9 January 2017).
} 


\section{${ }^{3}$ See}

http://pdf.savills.com/documents/Foreword\%20by\%20Community\%20Secretary,\%20Eric\%20Pickles\%20and\%20t he\%20regeneration\%20research\%20proposal.pdf (accessed 9 January 2017).

${ }^{4}$ For recent research on this contentious topic, see the following report http://www.engineering.ucl.ac.uk/engineering-exchange/files/2014/10/Report-Refurbishment-DemolitionSocial-Housing.pdf (accessed 9 January 2017).

${ }^{5} \mathrm{~A}$ good definition of social rented housing is given here: https://www.gov.uk/definitions-of-general-housingterms\#social-and-affordable-housing. (accessed 9 January 2017).

${ }^{6}$ For a mapping of the displacement of tenants and leaseholders from Southwark's Heygate Estate, see Loretta Lees, Just Space, and SNAG (Southwark Notes Archives Group) 'The Social Cleansing of Council Estates in London', Ben Campkin, David Roberts and Rebecca Ross (eds), Regeneration Realities: Urban Pamphleteer, n. 2 (2014), pp. 6-11.

${ }^{7}$ Compulsory Purchase Orders are issued to those same residents that the Councils earlier sold 125 -year leases under the 'right to buy'. See https://www.gov.uk/right-to-buy-buying-your-council-home/overview (accessed 9 January 2017). As one recent legal case shows, urban blight is currently calculated to reduce the value of a property for sale by only $10 \%$. See for example https://southwarknotes.wordpress.com/aylesbury-estate/ (accessed 9 January 2017) and http://35percent.org/2014-05-30-aylesbury-leaseholder-fights-incestuousvaluation/ (accessed 9 January 2017).

${ }^{8}$ This statement has been edited slightly here to fit word length requirements. For the full statement see http://crappistmartin.github.io/images/SummaryProfRendell.pdf (accessed 9 January 2017).

${ }^{9}$ Witness Statement of an Aylesbury Leaseholder, 25 April 2015.

${ }^{10}$ See The London Borough of Southwark, Town and Country Planning Act 1990 and Acquisition of Land Act 1981, The London Borough of Southwark (Aylesbury Estate Sites 1B-1C) Compulsory Purchase Order 2014, Statement of Case made by the London Borough of Southwark under Rule 7 of the Compulsory Purchase (Inquiries Procedure) Rules 2007.

${ }^{11}$ See Loretta Lees, 'The Urban Injustices of New Labour's "new urban renewal" the case of the Aylesbury Estate', accessed at https://southwarknotes.files.wordpress.com/2009/12/lorettalees pptx.pdf. See also Campkin, Remaking London for his chapter on the Aylesbury and wider look at 'regeneration'. Ben Campkin, Remaking London: Decline and Regeneration in Urban Culture, (London: IB Tauris, 2013), especially 77-107.

${ }^{12}$ See http://35percent.org/; http://betterelephant.org/; and https://southwarknotes.wordpress.com/(accessed 9 January 2017).

${ }^{13}$ See Donna Haraway, 'Situated Knowledges: The Science Question in Feminism and the Privilege of Partial Perspective', Feminist Studies, v. 14, n. 3, (Autumn 1988), 575-99 and D. Soyini Madison, Critical Ethnography: Method, Ethics and Performance (London: Sage, 2012).

${ }^{14}$ See the description of this part of the Aylesbury Estate as 'the order land', in The London Borough of Southwark, Statement of Case made by the London Borough of Southwark under Rule 7 of the Compulsory Purchase (Inquiries Procedure) Rules 2007, p. 1 and throughout

${ }^{15}$ For secondary sources on Roehampton see for example Joseph Rykwert, 'Architecture', Boris Ford (ed.) Modern Britain: The Cambridge Cultural History, [1988] (Cambridge: The University of Cambridge, 1992), 253-77; Simon Pepper, 'Housing at Roehampton', Ford (ed.) Modern Britain, 279-87; and descriptions in Bullock, Nicholas, Building the Post-War World: Modern Architecture and Reconstruction in Britain (London: Routledge, 2002); Glendinning, Miles and Stefan Muthesius, Tower Block: Modern Public Housing in England, Scotland, Wales and Northern Ireland (London and New Haven: Yale University Press, 1994); and John R. Gold, The Practice of Modernism: Modern Architects and Urban Transformation, 1954-1972 (Abingdon: Routledge, 2007).

${ }^{16}$ For the initial designs see, Le Corbusier et P. Jeanneret, Oeuvre complete 1938-1946, v. 4, publié par Willy Boesiger, architecte, Zurich (Erlenbach-Zurich: Les Editions d'Architecture Erlenbach-Zurich, 1946), 172-87. See also Le Corbusier, The Marseilles Block, [1950] translated by Geoffrey Sainsbury, from the French Unité d'Habitation de Marseille (London: The Harvill Press, 1953), where Le Corbusier describes it as 'a block of 360 
flats', see 7, and as 337 homes, see 42 . For specific contemporary commentaries and discussions, see Alban Janson and Carsten Krohn, Le Corbusier, Unité d'habitation, Marseilles, (London and Stuttgart: Axel Menges, 2007) and Jacques Sbriglio, Le Corbusier: The Unité d'Habitation in Marseilles, and Rez-les-Nantes, Berlin, Briey en Foret, Firminy, (Basel, Boston, Berlin and Paris: Birkhauser Publishers and Fondation Le Corbusier, 2004).

17 See Contemporary Architecture (1929) n. 5, 158-64 for plans and Contemporary Architecture (1930) n. 5, 6-13 for photographs of the just completed building. For Catherine Cooke's translation of Moisei Ginzburg, 'Housing Complex for Employees of Narkomfin, Moscow', Contemporary Architecture (1929) n. 5, 161-2, see Cooke, Russian Avant-Garde, p. 120. See also Victor Buchli, 'Moisei Ginzburg's Narkomfin Communal House in Moscow', Journal of the Society of Architectural Historians, (1998) v. 57, n. 2, 160-81.

${ }^{18}$ See David Lewis, 'Criticism', Sheffield, A Special Number edited by Pat Crook, Architectural Design, (September 1961), 397-8; 'Housing at Park Hill and Hyde Park, Sheffield', The Architects' Journal Information Library (21 July 1965), 160; and 'Park Hill Development', The Architects' Journal (23 August 1961), 272.

${ }^{19}$ See the work of Richard Baxter on the importance of the view to Aylesbury residents. See Richard Baxter, QMUL, and Mark Davidson, Clark University, 'The Violence of Urban Regeneration: Home and Place Unmaking in the Gentrification of the Aylesbury Estate', (April 2015) and Richard Baxter, 'The High-Rise Home: Practices of Verticality on the Aylesbury Estate' (April 2015), paper submitted to the International Journal of Urban and Regional Research.

${ }^{20}$ See http://www.savills.co.uk/ news/article/72418/175241-0/4/2014/savills-research--london-regenerationresearch-proposal (accessed 9 January 2017).

\section{${ }^{21}$ See}

http://pdf.savills.com/documents/Foreword\%20by\%20Community\%20Secretary,\%20Eric\%20Pickles\%20and\%20t he\%20regeneration\%20research\%20proposal.pdf (accessed 9 January 2017).

22 See the report by Nicholas Boys Smith and Alex Morton, 'Create Streets; Not just Multi-Storey Estates' at http://www.createstreets.com/ (accessed 22 July 2016). See also Create Streets' 'Better Regeneration' and 'Why aren't we building more streets?' and Savills, 'Completing London's Streets: Savills Research Report to the Cabinet Office' (2016) http://www.createstreets.com/reports/4589645468 [accessed 29 July 2016].

${ }^{23}$ See for example Baxter, 'The High-Rise Home'.

${ }^{24}$ See Lees, 'The Urban Injustices of New Labour's "new urban renewal"' and Campkin, Remaking London.

${ }^{25}$ See The London Borough of Southwark, Statement of Case made by the London Borough of Southwark under Rule 7 of the Compulsory Purchase (Inquiries Procedure) Rules 2007, p. 4, para. 1.11.

${ }^{26}$ The Office of the Deputy Prime Minister, Compulsory Purchase and the Crichel Down Rules (2004), p. 7, para. 17. See https://www.gov.uk/government/uploads/system/uploads/attachment data/file/7691/1918885.pdf (accessed 22 July 2016).

${ }^{27}$ European Court of Human Rights, Protocol of the Convention for the Protection of Human Rights and Fundamental Freedoms (1952), Article 1, p. 31. See http://www.echr.coe.int/Documents/Convention ENG.pdf [accessed 29 July 2016].

${ }^{28}$ The London Borough of Southwark, Statement of Case made by the London Borough of Southwark under Rule 7 of the Compulsory Purchase (Inquiries Procedure) Rules 2007, p. 30.

${ }^{29}$ The London Borough of Southwark, Statement of Case made by the London Borough of Southwark under Rule 7 of the Compulsory Purchase (Inquiries Procedure) Rules 2007, p. 30, para 9.5.

30 The Office of the Deputy Prime Minister, Compulsory Purchase and the Crichel Down Rules (2004), p. 7, para. 19. https://www.gov.uk/government/uploads/system/uploads/attachment data/file/7691/1918885.pdf, see (accessed 9 January 2017).

31 The London Borough of Southwark, Statement of Case made by the London Borough of Southwark under Rule 7 of the Compulsory Purchase (Inquiries Procedure) Rules 2007, pp. 8-9, para. 5.2. 
32 See Alan Conisbee and Associates, Aylesbury Estate: Robustness Considerations to Inform Risk Assessments, (10 March 2005), job no. 050041. Obtained from Southwark Council under FOI 493517.

33 The London Borough of Southwark, Statement of Case made by the London Borough of Southwark under Rule 7 of the Compulsory Purchase (Inquiries Procedure) Rules 2007, pp. 6-7, para. 4.2.

${ }^{34}$ Southwark Council, Southwark's objection statement version 2 - ALG Statement of case updated pdf, (24 April 2015), p. 21, points 2.04-2.06.

${ }^{35}$ The London Borough of Southwark, Statement of Case made by the London Borough of Southwark under Rule 7 of the Compulsory Purchase (Inquiries Procedure) Rules 2007, pp. 2-3, para. 1.6.

${ }^{36}$ See Equalities Impact Assessment for Aylesbury Area Action Plan (January 2009), p. 8. This is no longer available on Southwark's website. So see

https://southwarknotes.files.wordpress.com/2009/12/equalities_impact_assessment1.pdf (accessed 9 January 2017).

37 Southwark Council, Revitalise: Aylesbury Area Action Plan (January 2010), p. 4. See http://www.2.southwark.gov.uk/download/downloads/id/13132/aylesbury area action plan 2010 inc append ices (accessed 9 January 2017).

38 The London Borough of Southwark, Statement of Case made by the London Borough of Southwark under Rule 7 of the Compulsory Purchase (Inquiries Procedure) Rules 2007, p. 32, point 5.

${ }^{39}$ See

https://www.whatdotheyknow.com/request/216037/response/534726/attach/html/2/Freedom\%20of\%20Infor mation\%20request\%20response\%20for\%20405721.pdf.html (accessed 9 January 2017).

40 See

https://www.whatdotheyknow.com/request/216037/response/543034/attach/html/3/lbsouthwark\%20cbarfield \%2025\%2007\%202014\%2011\%2004\%2032.pdf.html (accessed 9 January 2017).

See also

http://www.peoplesrepublicofsouthwark.co.uk/index.php?option=com content\&view=article\&id=3656:13-daysleft-to-object-to-demolition-of-the-aylesbury-estate\&catid=21:news\&ltemid=156 (accessed 9 January 2017).

${ }^{41}$ Lees, Just Space, and SNAG (Southwark Notes Archives Group) 'The Social Cleansing of Council Estates in London'.

${ }^{42}$ See http://35percent.org/2013-06-08-the-heygate-diaspora/ (accessed 9 January 2017).

${ }^{43}$ See http://www.insidehousing.co.uk/journals/2015/02/11/t/u/j/KnockltDownorDoltUp.pdf (accessed 9 January 2017).

${ }^{44}$ See http://www.primelocation.com/newhomes/details/35797322?search identifier=655ae7d606b9ab6729f3c4798d354200\#rWFcveMRhiC3eWJS.97 (accessed 9 January 2017).

45 The London Borough of Southwark, Statement of Case made by the London Borough of Southwark under Rule 7 of the Compulsory Purchase (Inquiries Procedure) Rules 2007, pp. 31-2, point 4.

${ }^{46}$ The London Borough of Southwark, Statement of Case made by the London Borough of Southwark under Rule 7 of the Compulsory Purchase (Inquiries Procedure) Rules 2007, p. 12, para. 5.02.

${ }^{47}$ See Equalities Impact Assessment for Aylesbury Area Action Plan (January 2009), p. 5. https://southwarknotes.files.wordpress.com/2009/12/equalities_impact_assessment1.pdf (accessed 9 January 2017).

${ }^{48}$ See the zoning of this development where Aylesbury leaseholders are being offered shared ownership deals. See https://www.nhhg.org.uk/residents/ (accessed 9 January 2017). 
${ }^{49}$ See https://southwarknotes.files.wordpress.com/2009/12/aylesbury-phase-1a.jpg (accessed 12 December 2015).

50 See http://betterelephant.org/blog/2015/02/06/aylesbury-estate-facts-and-figures/ and http://moderngov.southwark.gov.uk/Data/Executive/20050927/Agenda/Item\%2007\%20\%20The\%20AylesburyEstate\%20Revised\%20Strategy\%20-\%20Report.pdf (accessed 9 January 2017).

${ }^{51}$ The London Borough of Southwark, Statement of Case made by the London Borough of Southwark under Rule 7 of the Compulsory Purchase (Inquiries Procedure) Rules 2007, p. 10, para. 5.11.

52 See Southwark Council, Revitalise: Aylesbury Area Action Plan (January 2010), p. 35, para. 3.3.5. See http://www.2.southwark.gov.uk/download/downloads/id/13132/aylesbury area action plan 2010 inc append ices (accessed 9 January 2017).

${ }^{53}$ The London Borough of Southwark, Statement of Case made by the London Borough of Southwark under Rule 7 of the Compulsory Purchase (Inquiries Procedure) Rules 2007, p. 31, point 3.

54 The email I received on 3 March 2015, in response to my request for information: 502731, in which I asked to see a copy of the Partnership Agreement between Notting Hill Housing Trust and London Borough of Southwark stated: 'Your request has been dealt under the Environmental Information Regulations 2004. In response to it we have enclosed a redacted version of Copy of the Partnership Agreement between Notting Hill Housing Trust and London Borough of Southwark.'

55 This included Alexander Vesnin, architect; Aleksei Gan, art critic and propagandist; Alexander Rodchenko, sculptor and photographer; Vladimir and Georgii Sternberg, poster designers; and Varvara Stepanova, set designer. See for example William Craft Brumfield, A History of Russian Architecture, (Cambridge: Cambridge University Press, 1993), p. 470.

${ }^{56}$ See for example Hugh Hudson, "The Social er of our Epoch": The Association of Contemporary Architects and the Creation of a New Way of Life in Revolutionary Russia', Jahrbücher für Geschichte Osteuropus, Neue Folge, Bd. 34, H. 4 (1986), pp. 557-78, pp. 558-9; and Anatole Kopp, Constructivist Architecture in the USSR (London, St Martin's Press, Academy Editions, 1985), p. 22. Kopp discusses how the Constructivist movement was set up on the basis of arguments made in Moisei Ginzburg's Style and Epoch [1924], which drew inspiration from articles published by Le Corbusier in L'Esprit Nouveau, and in Towards a New Architecture. Catherine Cooke compares the two books, and argues that if one considers the discussions of the 'machine à habiter', for example, in both works, then Ginzburg's development of 'a quite sophisticated methodological concept' leaves Le Corbusier's work in the 'realm of aphorisms'. See Catherine Cooke, Russian Avant-Garde: Theories of Art, Architecture and the City (London: Academy Editions, 1995), p. 109. Anatole Senkevitch notes that while Ginzburg would not have read Towards a New Architecture, he would have seen the series of essays, albeit in a different order, which were published in the journal L'Esprit Nouveau in 1920-2 and which reached Moscow by the autumn of 1922 . See also Anatole Senkevitch, 'Introduction', in Moisei Ginzburg, Style and Epoch: Problems of Modern Architecture, pp. 10-33, p. 26. Major influences on constructivist method from art/graphic design included Alexei Gan, Constructivism (Tver, 1922), and the film by Sergei Eisenstein, The General Line (1929), which showed models constructed to full size sets all to designs in 1926 by Andrei Buruv.

${ }^{57}$ As Jean-Louis Cohen notes, the term 'contemporary' in its title was used to mark out the interests of the group as distinct from modernistic, the word used at the time to describe art nouveau. See Jean-Louis Cohen, 'An Extraordinary Pyatiletka of Sovremennaia Arkhitektura', in the reprinted editions of Contemporary Architecture (Sovrenennaja architektura, SA), 1926-30 (Yekaterinburg: Tatlin Publishing House, 2010), pp. 2-31, p. 9.

58 Ginzburg, quoted in Hudson, “"The Social Condenser of our Epoch”', p. 559.

${ }^{59}$ Moisei Ginzburg, in Contemporary Architecture (1927), n. 6, p. 160, quoted in Ross Wolfe, The Graveyard of Utopia: Soviet Urbanism and the Fate of the International Avant-Garde, see

https://rosswolfe.files.wordpress.com/2011/09/ross-wolfe-the-graveyard-of-utopia-soviet-urbanism-and-thefate-of-the-international-avant-garde.pdf (accessed 7 January 2017).

${ }^{60}$ Moisei Ginzberg in Contemporary Architecture, (1927) n. 6, p. 160, quoted by Wolfe, The Graveyard of Utopia.

61 I explore this genealogy and history in Jane Rendell, The Architecture of Psychoanalysis: Spaces of Transition (London: IB Tauris, 2016). 
${ }^{62}$ See for example, https://www.architectsjournal.co.uk/news/javid-rejects-aylesbury-estate-cpo-as-breach-ofhuman-rights/10011883.article (accessed 7 January 2017) and http://35percent.org/2016-09-18-aylesburycompulsory-purchase-order-rejected/ (accessed 7 January 2017).

${ }^{63}$ See http://35percent.org/2016-09-18-aylesbury-compulsory-purchase-order-rejected/ (accessed 7 January 2017). 